\title{
Vi bør slutte å bruke ordet dement
}

\author{
Ordet «dement» dukker med jevne mellomrom opp i Tidsskriftets spalter. Ved å bruke formuleringer som \\ «han er dement», karakteriserer man mennesket gjennom sykdommen. Dette er umenneskelig, stigmatise-
} rende og diskriminerende.

Innen fagfeltet demens vil man nesten være tilbøyelig til å se på helsearbeidere som halvstuderte røvere dersom de omtaler en person som «dement». Vedkommende pasient er nemlig enten demenssyk, lider av en demenssykdom eller har en demenssykdom. Man bør også unngå å si at en person «har fått» en demenssykdom. Når man «får» noe, er det et verb som assosieres med det å «få en gave». Det blir derfor egentlig grotesk å formulere seg slik at det kan høres ut som om det å bli rammet av en demenssykdom er «en gave».

Grunnen til denne presiseringen er at ved å omtale en person som «dement», ser man ikke lenger på personen som et individ, men setter likhetstegn mellom individet og sykdommen. Man gjør pasienten til sykdommen, og pasienten karakteriseres, identifiseres og personifiseres som en sykdom.

Helsetjenestesjargongen for noen tiår siden var preget av en tendens til ubetenk- somt å avpersonalisere pasienten. Man lot ikke pasienten få være det mennesket og det egne individ som pasienten selvfølgelig alltid har vært og alltid vil forbli og alltid vil ha krav på å få være. Klassiske eksempler på dette var å omtale en pasient som «lårhalsbruddet i 2 -sengen på 403», «nyresteinen i 3-sengen på 214», «dyspeptikeren på 107», for ikke å snakke om «aborten i 2-sengen på 309». Dette er eksempler som åpenbart avslører umenneskeliggjøringen og avpersonaliseringen av pasienten. Enhver som hører noe slikt vil jo - eller burde i alle fall - reagere. Det henger nok dessverre til en viss grad igjen også i dagens språkbruk.

Men fordi det å snakke om «de demente» er blitt en så integrert del også av ikke-fagpersoners dagligtale, gjennomskues ikke dette like lett som de øvrige ovenfornevnte helt analoge eksemplene.

Temaet er omtalt i Tidsskriftet tidligere, bl.a. av nevrologen Karl O. Nakken som

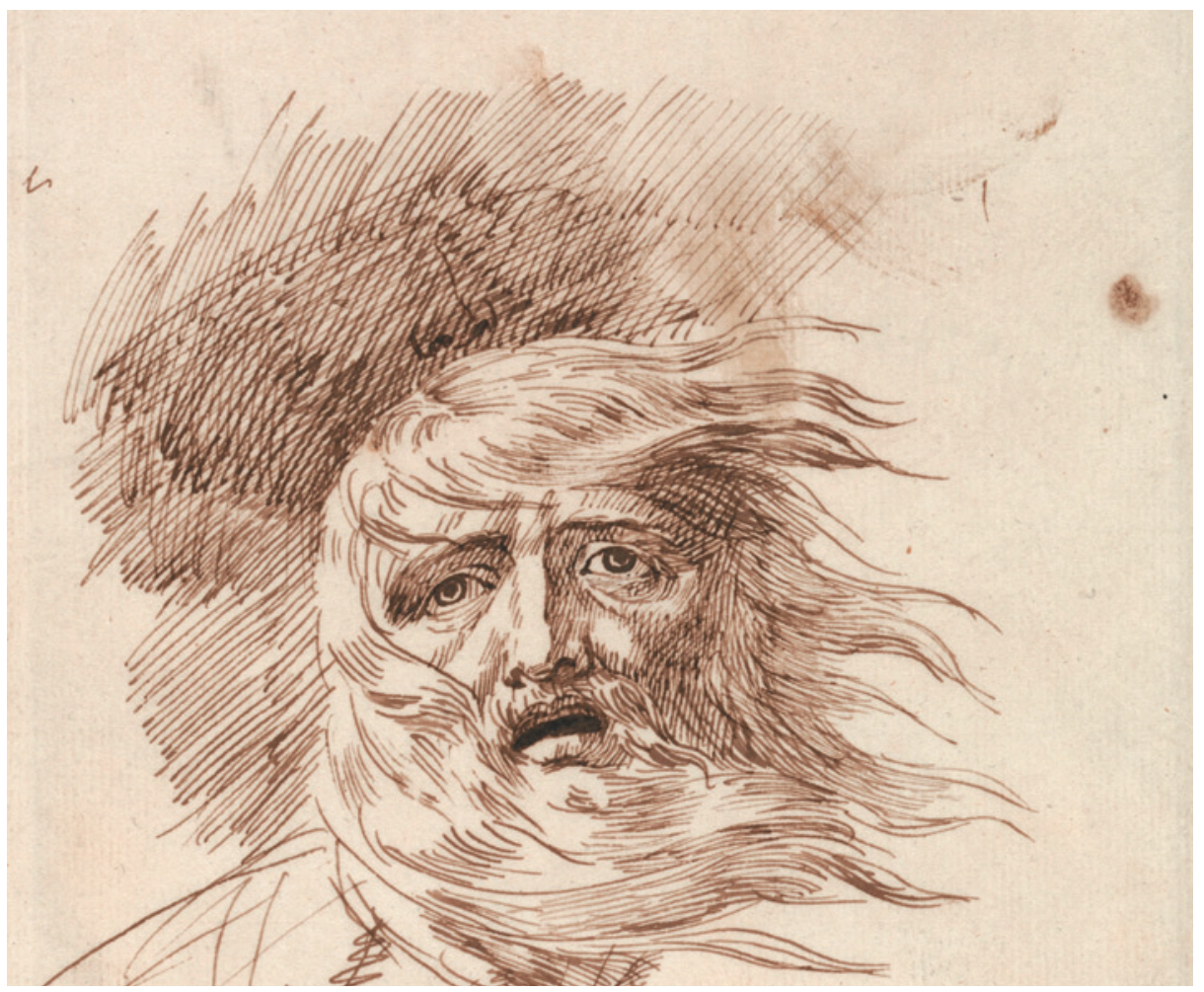

Var kong Lear dement, et menneske med demens - eller kanskje ikke? Her er «Lear i stormen» («Lear in the Storm»), en udatert tegning av George Romney (1734-1802). The Yale Center for British Art, Yale University, New Haven, Connecticut. Wikimedia Commons påpekte at man ikke bør snakke om «epileptikere», men om mennesker med epilepsi: «Epilepsi er noe jeg har, ikke noe jeg er» (1). På samme måte ville en demenssyk pasient si at «demens er noe jeg har, ikke noe jeg er». Eller bedre: «Demens er en sykdom jeg lider av, ikke noe jeg er».

De aller fleste epileptikere fungerer så bra kognitivt at de vil kunne sette ord på dette, mens en demenssyk, selv i et tidlig sykdomsstadium, med kognitiv svikt og ledsagende anomisk afasi (språksvikt med ordletings-/ordfinningsproblemer) ikke evner dette. Den demenssyke vil derfor ikke kunne forsvare seg på samme måte som den kognitivt velfungerende epilepsipasienten.

\section{Olav Aga}

olavaga@broadpark.no $\emptyset$ vre Eiker

Olav Aga (f. 1938) er tidligere sykehjemsoverlege.

\section{Litteratur \\ 1. Nakken KO. Betegnelsen epileptiker bør unngås. Tidsskr Nor Legeforen 2013; 133: 1088}

\section{Erlend Hem svarer:}

I forrige nummer av Tidsskriftet mente Jøran Hjelmesæth at vi bør unngå å skrive «sykelig overvektige personer» til fordel for «personer med sykelig overvekt» (1). Olav Aga argumenterer her for det samme: Vi bør droppe ordet «dement» og heller snakke om «mennesker med demens».

Språkrådet ønsker ikke å gi en slik anbefaling $(2,3)$. Vi har denne gang spurt FinnErik Vinje, professor emeritus i nordisk språkvitenskap, til råds. Her er hans svar:

\section{Finn-Erik Vinjes vurdering}

Jeg skal fatte meg i korthet om dette interessante språkpsykologiske og språksosiologiske emne. Her følger noen randbemerkninger.

I siste instans dreier det seg om forholdet mellom språk og tanke. Man kan spørre: Er vår tanke bastet og bundet til de konvensjonelle språklige størrelser? Former våre ord den virkelighet vi lever $\mathrm{i}$, 